\title{
Strengthening community support, resilience programmes and inter- ventions in infectious diseases of poverty
}

Ernest Tambo ${ }^{1,2}$, Jeanne Y. Ngogang ${ }^{1}$, Xiao Ning ${ }^{3,4}$ and Zhou Xiao-Nong ${ }^{3,4,5}$

${ }^{1}$ Department of Biochemistry, Higher Institute of Health Sciences, Université des Montagnes, Bangangté, Cameroon. ${ }^{2}$ Africa Intelligence and Surveillance, Communication and Response Foundation (Africa DISCoR), Yaoundé, Cameroon (Correspondence to: E. Tambo: tamboo711@gmail.com). ${ }^{3}$ National Institute of Parasitic Diseases, Chinese Center for Disease Control and Prevention, Shanghai, China. ${ }^{4}$ Key Laboratory of Parasite and Vector Biology of the Chinese Ministry of Health, Shanghai, China. ${ }^{5}$ WHO Collaborating Centre for Tropical Diseases, Shanghai, China.

\begin{abstract}
Background: There is an urgent need to promote innovative partnerships, community leadership and commitment toward strengthening coherent and sustainable community support, resilience programmes, engagement and social mobilization for resiliency.

Aims: This paper aims to strengthen coherent, scalable and sustainable community participation, resilience policies and innovative programmes to accelerate elimination and eradication of infectious diseases of poverty.

Methods: An unstructured and retrospective review approach was used to determine and to define full papers, reviewed publications, and grey literature on the topics of community resilience, infectious diseases of poverty elimination and eradication, and the global health security agenda.

Results: Little is documented on individual and community responsibility cooperation in elimination of infectious diseases of poverty through surveillance and resilience, eradication programmes and interventions. Hence, it is essential to develop joint ownership of community infectious diseases, or emerging outbreaks projects, that can play an important role in research and policy decisions, and advance new cultural and psychobehavioural public health directions. Such an enabling environment is imperative to improve accessibility and availability to essential medical and pharmaceutical commodities in the supply chain management.

Conclusions: It is essential to strengthen effective community-based access to drugs and vaccine coverage and effectiveness procurement systems. This is required to improve access to and uptake of care service delivery and management, monitoring and evaluation of integrated and cost-effective programmes, Sustainable Development Goals, and upholding global health security.

Keywords: Community programmes, community resilience, disease eradication, infectious diseases, poverty

Citation: Tambo E; Ngogang JY; Ning X; Xiao-Nong Z. Strengthening community support, resilience programmes and interventions in infectious diseases of poverty. East Mediterr Health J. 2018;24(6):598-603. https://doi.org/10.26719/2018.24.6.598

Received: 15/02/17; accepted: 29/05/17

Copyright (c) World Health Organization (WHO) 2018. Some rights reserved. This work is available under the CC BY-NC-SA 3.o IGO license (https:// creativecommons.org/licenses/by-nc-sa/3.o/igo).
\end{abstract}

\section{Introduction}

Infectious diseases of poverty still afflict millions of people with serious disabilities and deformities, killing almost 1.1 million people, and exact an enormous public health burden and cost on the developing world (1). Formal eradication campaigns were initiated for malaria in 1960-1976, dracunculiasis and leprosy in 1991, and polio, onchocerciasis and lymphatic filariasis in 1988, 1997 and 2000 respectively $(2,3)$. Subregional campaigns in Africa have eliminated measles and are also underway for elimination of onchocerciasis and Chagas' disease. Smallpox and measles elimination and eradication programmes have yielded valuable lessons that have since been applied to other infectious diseases; mainly value-added, evidence-based information and integrated surveillance and response to garner resources and capability for concerted and coherent national and global partnerships, frameworks and actions plans $(1,4)$. The programmes have also shown that eradication can be achieved with cost-effective, all-inclusive, community-based pro- grammes and interventions to prevent and interrupt mosquito vector transmission and spread of insecticide/ drug resistance in advancing malaria, schistosomiasis, TB/HIV and polio elimination and ultimate eradication. Moreover, the programmes have improved strategies for promoting sustainable community engagement and risk communication that are needed to promote participation of vulnerable communities and community health workers. The programmes have also increased access to and uptake of national healthcare delivery programmes and medical resources, including scaling up national immunization coverage and effectiveness, and increasing supply chain management and quality health outcomes $(2,5)$. Implementation of effective strategies and sustainable development programmes in communities and national governments is required to improve infectious diseases elimination, poverty alleviation and response to the threat of emerging pandemics. Also, promoting understanding of local culture, behaviour and practice is needed to guide community empowerment and cohesive systems for enhanced health data sharing and con- 
stant risk communication to tackle the vicious cycle of poverty and health system inequalities $(6,7)$. For example, the lymphatic filariasis and onchocerciasis control programmes for West Africa have been ongoing for $>17$ years and are likely to reach their elimination targets according to the World Health Organization (WHO) (8). However, WHO is still on risk mapping and stratification of most infectious diseases of poverty (including neglected tropical diseases [NTDs] and NCDs) prevalence for the 19 African countries in the most recent sustained control to elimination programmes. The Roll Back Malaria initiative in 2008, followed by The Global Fund to Fight AIDS, Tuberculosis and Malaria, have significantly reduced public health burden in some African countries, thus providing hope of elimination. For example, scaling up proven, integrated national malaria control, elimination and eradication programmes and interventions, mainly artemisinin combination therapy, insecticide-treated bednets and insecticide residual spraying is crucial for acceleration of evidence-based national programmes in Africa and elsewhere (7,9-11). However, malaria alone still kills almost 1 million children each year - the majority in the least developed countries, mainly in sub-Saharan Africa $(12,13)$. Although antiretroviral therapy can manage human immunodeficiency virus (HIV) infection by prolonging and improving quality of life, an estimated 33 million people are living with HIV today, with a further 2.7 million new infections occurring annually due to social and cultural practices, and behavioural and economic challenges (12-14).

It is vital to assess how changes in community roles and positive behavioural changes can identify new expectations and targets, while building important skills, knowledge and best practices in diseases elimination and eradication. Development of in-depth operational research in vulnerable communities is core to sustained partnerships and resource mobilization, as well as promoting community resiliency building (15). Understanding the spatial and geographical heterogeneity of pathogens and mosquito vectors, the different extent and nature of disease, and the effectiveness of national programmes in different communities is needed to generate evidence-based community elimination programmes. There is also a need to establish, through robust political leadership and financial commitment, coherent and sustainable community-based programmes for elimination and eradication of infectious diseases of poverty and emerging epidemics, based on equity and inclusiveness, coverage and operational challenges (16, 17). Other contextual control measures include social and behavioural characteristics, intervention coverage, mass drug administration, intermittent preventive chemotherapy or vaccine acceptance and coverage, and populations' connectedness (16-19). Yet, most endemic communities are readily embarking on programmes to end the scourge of infectious diseases $(17,19,20)$. Strengthening and improving primary healthcare delivery systems to reduce morbidity to a level at which it is no longer considered a major public health problem, and eradication of infectious diseases, involve reducing worldwide incidence to zero, thereby obviating the need for further evidence-based active surveillance, monitoring and quality management systems, and effective elimination measures. Public health medicine has enjoyed periodic major successes in the control of infectious diseases as result of multilateral partnerships, leadership, and commitment towards elimination (21). For example, achieving polio eradication in most affected countries in Africa requires mobilization of sufficient resources to improve mass/targeted vaccination commitment and surveillance campaigns; strengthening cold supply chain and vaccination coverage rates; timely communication and reporting; and increased incentivizing of community health workers at all levels (22).

This paper aims to strengthen coherent, scalable and sustainable community support and resilience policies and innovative programmes to accelerate eradication of infectious diseases of poverty, eliminate the threat of emerging pandemics, and improve global health security.

\section{Strengthening community engagement and participation in sustainable health services delivery innovations}

There is an urgent need for effective support, community social mobilization and awareness outreach for resiliency, community-based partnership, programmes or projects ownership, shared responsibility and participation in elimination (23). Increasing government funding allocation and financial resource commitment, inclusiveness and social equality is core to boosting citizenry resilience and empowerment strategies, and tackling the persistent drawbacks and challenges facing infectious diseases elimination and eradication in Africa and elsewhere $(23,24)$. There is also a need for technical assistance and active community participation in decision-making policy to provide equitable service delivery and immunization programmes coverage to have an impact in all affected and remote settings. Community social and economic capacity building in full participation and project ownership can play an important role in positive rethinking and upholding new cultural and psychobehavioural directions $(16,23)$.

There is a need for robust and practical communitybased support and resilient surveillance and response systems that highlight the importance of an effective and sustained partnership with local community, nongovernmental organizations, schools and faith-based groups. As such, scaling up access to and use of reliable and low-cost mobile health and social media technologies is core to increase adherence to bednets ownership and drug prescription, combating drug/insecticide resistance, and best practices in infectious disease elimination and eventual eradication (24-26). Thus, evidence supporting policy uptake of concerted and coordinated communitybased programmes and interventions is core to achieving elimination of infectious diseases of poverty in developing countries mainly in Africa, Latin America and Asia-Pacific regions. 
Developing contextual research needs for defining priorities, improving care management and integrated vector management approaches, and potential outbreak preparedness is needed through more sensitive early detection and surveillance methods of salient hotspots, reservoirs and asymptomatic cases, and building rapid response and best practice capabilities. It also relies on maintaining safety and quality standards of national programmes in all rural and remote settings, performance and effectiveness metrics in understanding the benefits and limitations $(2,27)$. Furthermore, improving quality healthcare services delivery and integration of health systems innovations is vital in tackling communicable diseases and emerging pandemics threats, and furthering regional/global elimination and eradication programmes.

\section{Developing and implementing improved community risk mapping and empowerment effectiveness initiatives}

Implementation of evidence-based and effective community-based programmes and interventions allows communities to be engaged and participate, gain new knowledge and confidence, and achieve self-care satisfaction Enabling these competencies and skills, coupled with technical assistance and policy guidelines, are important in improving delivery of quality care services and health systems to strengthen eradication of infectious diseases and elimination of pandemic threats $(28,29)$. Building the capacity to respond resiliently, adequately, timeously and firmly to challenges within the communities (30). Importantly, political leadership and policy decisions necessitate cost-benefit analysis of insourcing and outsourcing community-based resources and health commodities mobilization. As well as financial allocation analysis and forecasting simulations in disease elimination and eventual eradication. Hence, comprehensive and sustainable community-based, national programmes for malaria, HIV, tuberculosis, neglected tropical diseases, and emerging pandemic threats require implementation of social resiliency and quality care programmes, including national health insurance schemes to scale up and improve access to universal health coverage, livelihood and wellbeing.

\section{Strengthening acceptable and effective intervention packages requires multidisciplinary and intersectorial linkage}

Advancing local, regional and global systems approaches, cooperation and coordination are needed to improve national surveillance and response to infectious diseases and emerging pandemics threats and existing burdens $(31,32)$. There is also a need for improved sanitation and access to potable drinking water, effective environment and waste management programmes, in addition to community resilience and incentives to reduce and eliminate poverty-associated diseases, and maternal and childhood morbidity and mortality (33).

Galvanizing collaborative support between new local and international (private-public) organizations and philanthropic bodies is necessary for continuous outcomes-based public health programmes, social mobilization, and ownership and resiliency interventions in elimination and eradication (34). Some vulnerable communities or countries will need more support than others, especially as their local health priorities include disease eradication and pandemic preparedness $(30,31)$. For example, it might be best for developing and developed countries to vaccinate above the level of herd immunity to eliminate a disease.

Social resiliency and social equality can lead to the benefits of lower infection rates and associated treatment costs, increasing health care access and risk reduction strategies in order to improve livelihood and productivity in countries that are prone to infectious diseases and pandemic threats $(3,7,25,30,35)$.

\section{Integration of outcome-based and sustainable social equality and community surveillance projects}

Integration of outcome-based and sustainable social equality and community surveillance projects is crucial for prevention of disease recurrence, rapid preparedness and establishment of early warning signals of epidemics. This requires a combination of routine and active case surveillance, monitoring and evaluation, especially during disease elimination, and certification of eradication campaigns and various integrated interventions $(21,32)$. Such integrated surveillance and response in elimination serves multiple purposes: prediction of and finding remaining cases of circulating infection; measuring and mapping uptake of vaccine or drugs; detecting emergence and spread of antimicrobial and insecticide resistance; and identifying populations at risk in remote settings in Africa, Latin America and Asia-Pacific region $(2,25,30,34)$. Also, identifying the remaining pockets of susceptible individuals and hotspots is essential for focused elimination and eradication efforts (31). Communities can become less engaged as disease incidence declines, and consequently less involved in control activities, or start actively refusing vaccination. Once elimination and eradication have been achieved, returns on investment, health and economic benefits are potentially infinite $(4,10,35)$.

\section{Addressing communication gaps and drawbacks in infectious disease elimination and eradication}

Fostering effective and sustained dialogue in infectious disease elimination requires cooperation and partnership, with ample investment and good governance among all stakeholders including governments, policymakers, communities and households. Hence, increased joint 
leadership and advocacy are crucial for robust community-based outbreak preparedness and awareness campaigns, improved national vector control interventions, and technical assistance implementation at all levels. Communication gaps can be addressed through contextual and outcomes-based programmes, and service delivery can be provided and maintained by broadcasting the right messages and simple information or precautions for community empowerment, along with lessons learnt and success stories to support quality risk communication strategies $(1,2,23)$.

Exploring outcomes of community-based models of care delivery that leverage increased acceptance, access to and use of mobile health and digital technology is needed. This should rely on the value of products to patients/ populations end-users applications and frameworks for measuring quality and cost-effectiveness of healthcare interventions (i.e., mass drug treatments, immunization, preparedness and surge capacity, etc.) to those in need in remote and low-resource settings $(3,4,17,20,35)$.

\section{Conclusion}

Successful control, elimination and eradication of infectious diseases of poverty rely on coherent, multifaceted community-based health programmes, innovations and actions plans, while upholding previous lessons learned. Hence, effective long-term stable, sustainable, integrated and coordinated community-based models and approaches should strengthen successful implementation of communities support and resilience programmes and ownership, and continuous health education, vigilance and preparedness for prevention against disease recurrence, sporadic outbreaks and importation of pathogens. Application of cutting edge science and technological innovations in understanding and improving community knowledge, cultural and behavioural attitudes, and practices in globalization and epidemiological transition are constituents in attaining the Sustainable Development Goals, healthier communities and global health security.

Funding: None.

Competing interests: None declared.

\section{Renforcement du soutien communautaire, des programmes de résilience et des interventions en matière de maladies infectieuses de la pauvreté}

\section{Résumé}

Contexte: Il existe un besoin urgent de promouvoir des partenariats innovants, le leadership et l'engagement communautaires pour renforcer, de façon cohérente et durable, le soutien communautaire, les programmes de résilience, l'engagement et la mobilisation sociale afin de permettre la résilience.

Objectifs : La présente étude vise à renforcer la participation communautaire, les politiques de résilience et les programmes innovants de façon cohérente, progressive et durable dans le but d'accélérer l'élimination et l'éradication des maladies infectieuses de la pauvreté.

Méthodes: Une analyse non structurée et rétrospective a été menée afin d'identifier et de sélectionner les articles complets, les publications revues et la littérature grise portant sur la résilience communautaire, l'élimination et l'éradication des maladies infectieuses de la pauvreté, ainsi que sur le programme mondial de sécurité sanitaire.

Résultats : Il existe peu de recherche documentée sur la responsabilité individuelle et collective de coopérer en vue de l'élimination des maladies infectieuses de la pauvreté grâce à la surveillance et la résilience, et aux programmes et interventions d'éradication. Il est donc essentiel de développer une responsabilité commune vis-à-vis de la prise en charge des maladies infectieuses ou des programmes concernant les flambées émergentes, qui puisse jouer un rôle important dans la recherche et les décisions politiques, ainsi que de faire progresser les nouvelles orientations culturelles et psycho-comportementales en matière de santé publique. Un tel environnement favorable est impératif pour améliorer l'accès aux produits médicaux et pharmaceutiques essentiels, ainsi que leur disponibilité dans la gestion de la chaîne d'approvisionnement.

Conclusions: Il est crucial d'améliorer l'accès communautaire aux médicaments et à la couverture vaccinale et de renforcer les systèmes d'achat de façon efficace. Ceci est nécessaire pour améliorer l'accès et le recours aux prestations de services de santé, la gestion, le suivi et l'évaluation de programmes intégrés et ayant un bon rapport coût-efficacité, les Objectifs de développement durable, ainsi que pour préserver la sécurité sanitaire mondiale.

$$
\begin{aligned}
& \text { تعزيز البرامج والتدخلات المتّسقة والمستدامة في بجال الدعم المجتمعي والقدرة على التصدّي للأمر اض المعدية للفقر : } \\
& \text { للقضاء عليها واستئصالها } \\
& \text { إرنست تامبو، جين ينكيو نغوغانغ، زياو -نينغ، جهو إكسياو -نونغ } \\
& \text { الخلاصة }
\end{aligned}
$$

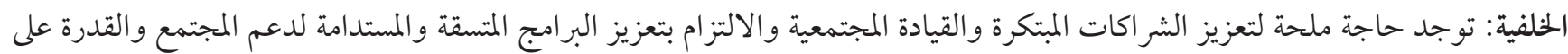

$$
\begin{aligned}
& \text { التصدي والمشاركة والتعبئة الاجتماعية لهذا التصديّي. }
\end{aligned}
$$


الهدف: تهدف هذه الورقة إلى تعزيز سياسات المشاركة المجتمعية والقدرة على التصدّي المتسقة والقابلة للتطوير والمستدامة و البرامج المبتكرة للتعجيل

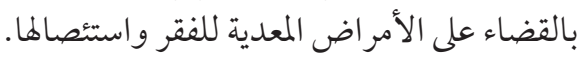

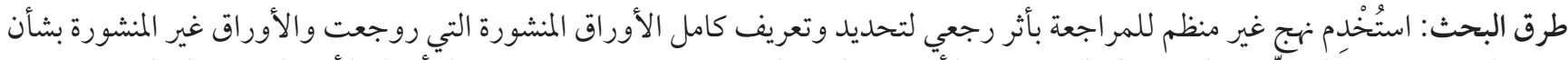

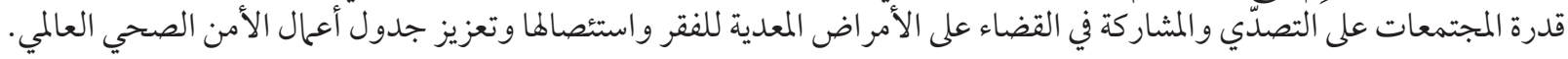

النتائج: لميوثق سوى القليل حول المسؤولية والمشاركة الفردية والمجتمعية في القضاء على الأمراض المعدية مجتمعية المنشأ للفقر وتر صدها و القدرة

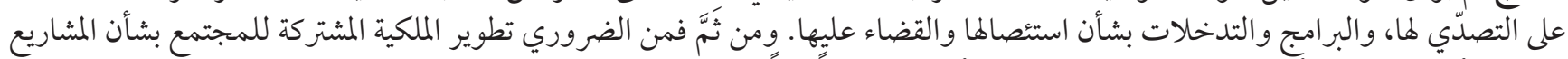

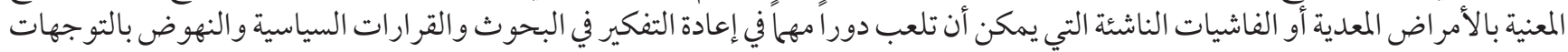

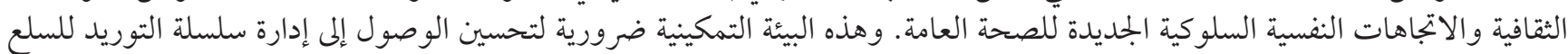

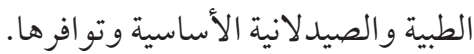

الاستنتاجات: هناك حاجة إلى تعزيز الوصول إلى خدمة الرعاية المجتمعية واستيعابها إلى أنظمة التغطية بالأدوية واللقاحات والحصول التحول عليها،

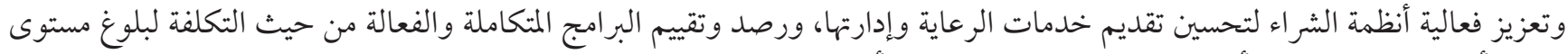

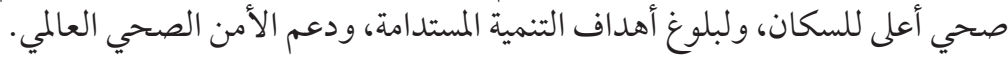

\section{References}

1. Klepac P, Metcalf CJ, McLean AR, Hampson K.. Towards the endgame and beyond: complexities and challenges for the elimination of infectious diseases. Philos Trans R SocLond B Biol Sci. 2013 Jun 24;368(1623):20120137. http://dx.doi.org/10.1098/ rstb.2012.0137 PMID:23798686

2. Klepac P, Funk S, Hollingsworth TD, Metcalf CJ, Hampson K. Six challenges in the eradication of infectious diseases. Epidemics. 2015 Mar;10:97-101. http://dx.doi.org/10.1016/j.epidem.2014.12.001 PMID:25843393

3. Smith DL, Cohen JM, Chiyaka C, Johnston G, Gething PW, Gosling R, et al. A sticky situation: the unexpected stability of malaria elimination. Philos Trans R SocLond B Biol Sci. 201306 24;368(1623):20120145. http://dx.doi.org/10.1098/rstb.2012.0145 PMID:23798693

4. Cairncross S, Tayeh A, Korkor AS. Why is dracunculiasis eradication taking so long? Trends Parasitol. 2012 Jun;28(6):225-30. http://dx.doi.org/10.1016/j.pt.2012.03.003 PMID:22520367

5. Fenner F. [Vaccination policies and the eradication of smallpox]. Rev Med Suisse Romande. 1999 Dec;119(12):985-92 (in French)

6. Cockburn TA. Eradication of infectious diseases. Science. 1961 Apr 7;133(3458):1050-8. http://dx.doi.org/10.1126/science.133.3458.1050 PMID:13694225

7. Whittaker MA, Dean AJ, Chancellor A. Advocating for malaria elimination - learning from the successes of other infectious disease elimination programmes. Malar J. 201406 5;13(1):221. http://dx.doi.org/10.1186/1475-2875-13-221 PMID:24902848

8. Cotter C, Sturrock HJ, Hsiang MS, Liu J, Phillips AA, Hwang J, et al. The changing epidemiology of malaria elimination: new strategies for new challenges. Lancet. 2013 Sep 7;382(9895):900-11. http://dx.doi.org/10.1016/So140-6736(13)60310-4 PMID:23594387

9. Sabot O, Cohen JM, Hsiang MS, Kahn JG, Basu S, Tang L, et al. Costs and financial feasibility of malaria elimination. Lancet. 2010 Nov 6;376(9752):1604-15. http://dx.doi.org/10.1016/So140-6736(10)61355-4 PMID:21035839

10. Nájera JA, González-Silva M, Alonso PL. Some lessons for the future from the Global Malaria Eradication Programme (19551969). PLoS Med. 2011 Jan 25;8(1):e1000412. http://dx.doi.org/10.1371/journal.pmed.1000412 PMID:21311585

11. Atkinson JA, Vallely A, Fitzgerald L, Whittaker M, Tanner M. The architecture and effect of participation: a systematic review of community participation for communicable disease control and elimination. Implications for malaria elimination. Malar J. 2011 Aug 4;10(1):225. http://dx.doi.org/10.1186/1475-2875-10-225 PMID:21816085

12. Nasir UN, Bandyopadhyay AS, Montagnani F, Akite JE, Mungu EB, Uche IV. Polio elimination in Nigeria: a review. Hum Vaccin Immunother. 2016 Mar 3;12(3):658-63. doi: 10.1080/21645515.2015.1088617

13. Meredith SE, Cross C, Amazigo UV. Empowering communities in combating river blindness and the role of NGOs: case studies from Cameroon, Mali, Nigeria, and Uganda. Health Res Policy Syst. 2012 May 10;10(1):16. http://dx.doi.org/10.1186/1478-4505-10-16 PMID:22574885

14. Molyneux DH. The 'neglected tropical diseases': now a brand identity; responsibilities, context and promise. Parasit Vectors. 2012 Jan 30;5(1):23. http://dx.doi.org/10.1186/1756-3305-5-23 PMID:22289579

15. Kaneko A. A community-directed strategy for sustainable malaria elimination on islands: short-term MDA integrated with ITNs and robust surveillance. Acta Trop. 2010 Jun;114(3):177-83. http://dx.doi.org/10.1016/j.actatropica.2010.01.012 PMID:20132788

16. Tambo E, Ugwu EC, Ngogang JY. Need of surveillance response systems to combat Ebola outbreaks and other emerging infectious diseases in African countries. Infect Dis Poverty. 2014 Aug 5;3(1):29. http://dx.doi.org/10.1186/2049-9957-3-29 PMID:25120913

17. Aylward B, Hennessey KA, Zagaria N, Olivé J-M, Cochi S. When is a disease eradicable? 100 years of lessons learned. Am J Public Health. 2000 Oct;90(10):1515-20. http://dx.doi.org/10.2105/AJPH.90.10.1515 PMID:11029980 
18. Andrews JM, Langmuir AD. The philosophy of disease eradication. Am J Public Health Nations Health. 1963 Jan;53(1):1-6. http:// dx.doi.org/10.2105/AJPH.53.1.1 PMID:14013067

19. Lo NC, Bogoch II, Blackburn BG, Raso G, N'Goran EK, Coulibaly JT, et al. Comparison of community-wide, integrated mass drug administration strategies for schistosomiasis and soil-transmitted helminthiasis: a cost-effectiveness modelling study. Lancet Glob Health. 2015 Oct;3(10):e629-38. http://dx.doi.org/10.1016/S2214-109X(15)00047-9 PMID:26385302

20. Adongo PB, Kirkwood B, Kendall C. How local community knowledge about malaria affects insecticide-treated net use in northern Ghana. Trop Med Int Health. 2005;10:366-78. http://dx.doi.org/10.1111/j.1365-3156.2005.01361.x PMID:15807801

21. Ajala AS, Wilson NA. Local aetiology and pathways to care in malaria among the Ibibio of South-coastal Nigeria. Health Cult Soc. 2013;4:80.

22. Brieger WR. Health education to promote community involvement in the control of tropical diseases. Acta Trop. 1996 Apr;61(2):93-106. http://dx.doi.org/10.1016/0001-706X(95)00104-M PMID:8740888

23. Dongus S, Pfeiffer C, Metta E, Mbuyita S, Obrist B. Building multi-layered resilience in a malaria control programme in Dar es Salaam, Tanzania. Prog Develop Stud. 2010;10:309-24.

24. Tambo E, Ai L, Zhou X, Chen J-H, Hu W, Bergquist R, et al. Surveillance-response systems: keys to elimination of tropical diseases. Inf Dis Poverty. 2014 May 27;3:17. http://dx.doi.org/10.1186/2049-9957-3-17 PMID:24971165

25. Marks M, Vahi V, Sokana O, Chi KH, Puiahi E, Kilua G, et al. Impact of community mass treatment with azithromycin for trachoma elimination on the prevalence of yaws. PLoS Negl Trop Dis. 2015 Aug 4;9(8):e0003988. doi: 10.1371/journal.pntd.0003988.

26. El Arifeen S, Christou A, Reichenbach L, Osman FA, Azad K, Islam KS, et al. Community-based approaches and partnerships: innovations in health service delivery in Bangladesh. Lancet. 2013;382:2012-26.

27. Lo NC, Bogoch II, Blackburn BG, Raso G, N'Goran EK, Coulibaly JT, et al. Comparison of community-wide, integrated mass drug administration strategies for schistosomiasis and soil-transmitted helminthiasis: a cost-effectiveness modelling study. Lancet Glob Health. 2015 Oct;3(10):e629-38. http://dx.doi.org/10.1016/S2214-109X(15)00047-9 PMID:26385302

28. Brieger WR, Sommerfeld JU, Amazigo UV, Network CDI; CDI Network. The potential for community-directed interventions: reaching underserved populations in Africa. Int Q Community Health Educ. 2015;35(4):295-316. http://dx.doi. org/10.1177/0272684X15592757 PMID:26470395

29. Witek-McManus S, Mathanga DP, Verney A, Mtali A, Ali D, Sande J, et al. Design, implementation and evaluation of a training programme for school teachers in the use of malaria rapid diagnostic tests as part of a basic first aid kit in southern Malawi. BMC Public Health. 2015 Sep 17;15(1):904. http://dx.doi.org/10.1186/s12889-015-2228-x PMID:26377070

30. Mishra SR, Khanal P, Karki DK, Kallestrup P, Enemark U. National health insurance policy in Nepal: challenges for implementation. Glob Health Action. 2015 Aug 21;8:28763. http://dx.doi.org/10.3402/gha.v8.28763. PMID:26300556

31. Gilbert JA, Long EF, Brooks RP, Friedland GH, Moll AP, Townsend JP, et al. Integrating community-based interventions to reverse the convergent TB/HIV epidemics in rural South Africa. PLoS One. 2015 May 4;10(5):e0126267. http://dx.doi.org/10.1371/journal. pone.0126267 PMID:25938501

32. O'Gorman CM, Smith MM, Oliffe JL, Leggo C, Korchinski M, Elwood MR. Community voices in program development: the wisdom of individuals with incarceration experience. Can J Public Health. 2012 Jul 18;103(5):e379-83. PMID:23617993

33. Maina LC, Karanja S, Kombich J. Immunization coverage and its determinants among children aged 12-23 months in a peri-urban area of Kenya. Pan Afr Med J. 2013;14:3. http://dx.doi.org/10.11604/pamj.2013.14.3.2181 PMID:23504493

34. Nikolay B, Mwandawiro CS, Kihara JH, Okoyo C, Cano J, Mwanje MT, et al. Understanding heterogeneity in the impact of national neglected tropical disease control programmes: evidence from school-based deworming in Kenya. PLoS Negl Trop Dis. 2015 Sep 30;9(9):e0004108. http://dx.doi.org/10.1371/journal.pntd.0004108 PMID:26421808

35. Lewis VA, Tierney KI, Fraze T, Murray GF. Care transformation strategies and approaches of accountable care organizations. Med Care Res Rev. 2017 Oct 1:1077558717737841 PMID: 29090623 